\title{
Improving Employee Performance Through Spiritual Intelligence and Organizational Citizenship Behavior
}

\author{
Ida Ayu Putu Widani Sugianingrat ${ }^{1}$, I Gede Aryana Mahayasa ${ }^{2}$, I Komang Dwi Yasa ${ }^{3}$, I Gede Agus Ari Eka Budi \\ Pratama $^{4}$ \\ ${ }^{1,2}$ Lecturer of the Magister Management of University of Hindu Indonesia \\ 3,4, 2 Student of the Magister Management of University of Hindu Indonesia \\ Email: widanidayu47@gmail.com
}

\begin{abstract}
This study aims to analyze the influence of spiritual intelligence and OCB on employee performance at the Denpasar City Social Service. The research population used were all 106 employees who were also used as research respondents. Data was collected using research questionnaires and distributed directly to the Denpasar City Social Service employees. The collected data is then processed with the SmartPLS 3.0 application program. The results showed that spiritual intelligence and OCB had a significant positive effect on employee performance. Spiritual intelligence also shows a significant positive effect on OCB. Furthermore, OCB acts as a partial mediation on the relationship of spiritual intelligence to the performance of Denpasar City Social Service employees. The dominant indicators that contribute to the spiritual intelligence of employees are self-knowledge, focus and contribution, and honesty. More specifically, it can be explained that self-knowledge, a better level of focus and higher honesty will be able to increase employee OCB. While the indicators of the dominant OCB variable in this case are civic virtue (responsibility) and sportsmanship (tolerance). This means that the higher the civic virtue (responsibility) and sportsmanship (tolerance) the employee will be able to improve the employee's performance.
\end{abstract}

Keywords: Spiritual intelligence, ocb, employee performance, civic virtue, sportsmanship, self-knowledge, focus and contribution, honesty

\section{Introduction}

Good employee performance is characterized by good quality work in completing every job given by the superior in a timely manner and can achieve every target set by the organization. Performance is a description of the level of achievement of the implementation of an activity program or policy in realizing the goals, objectives, vision, and mission of the organization as outlined through the strategic planning of an organization (Moeheriono, 2012:95). According to Sedarmayanti (2011: 260), performance is the result of the work of a worker, a management process or an organization as a whole, where the results of the work must be shown concrete and measurable evidence.

Performance, of course, does not stand alone. Because there are many factors - factors that affect performance, companies need to know what affects the performance. One that affects the level of intelligence of human resources. Intelligence is the ability to solve problems or create something of value for a particular culture (Gardner (in Efendi, 2005:79)). One type of intelligence that is of concern today is spiritual intelligence. Zohar \& Marshall (2007:4) argues that spiritual intelligence contained in a person is able to help move one's intellectual intelligence and emotional intelligence to be more active.

An intelligent employee is not only expressed by having a high IQ, but must also have good spiritual intelligence. Spiritual intelligence is the ability to adjust the rules followed by understanding and love, intelligence that places our life behavior in the context of a wider and richer meaning, and intelligence to judge that one's actions or way of life are more valuable and meaningful (Zohar and
Marshal, 2002:37). ). Where employees know that at work also requires honesty and a high awareness of responsibilities that must be completed, because what is done is something that must be accounted for to others and to God Almighty. Therefore, spiritual intelligence is able to integrate IQ (Idrus, 2002:57).

Spiritual intelligence allows a person to think creatively, be far-sighted, make or even change rules, which makes the person able to work better. Several research results found a significant positive correlation between spiritual intelligence on employee performance, including by research from Lie et al. (2021); Arifin (2019); Khandan et al. (2017) and Jasour et al. (2016). The results of this study agree with research conducted by Amirkhani \& Yosefi (2015) which states that there is a significant positive influence between spiritual intelligence on employee performance, with good spiritual intelligence, employees tend to be able to produce good work output as well.

However, research by Khairat (2017) shows the results that there is no significant influence between spiritual intelligence on employee performance. So even though employees have high spiritual intelligence, it will not have an effect on the work achieved. This result is in line with the research of Ratnasari et al. (2020) which shows that spiritual intelligence has no significant effect on employee performance. Based on the inconsistency of the results of previous studies, this study uses an intermediate variable, namely organizational citizenship behavior (OCB) to prove the relationship between spiritual intelligence and employee performance.

Moosapour (2013) in his research states that the influence of spiritual intelligence on OCB is significantly positive, it is 
said that if an employee has high spiritual intelligence, then the employee is also easier to generate positive emotions to do tasks or work extra. This statement is reinforced by research from Indriani \& Sari (2017); Alamanda et al. (2021); Sanjay (2021); Radiany \& Radiany (2021); which states that spiritual intelligence has a positive and significant influence on OCB, so that a person's spiritual intelligence is able to make employees have extra role behavior.

Furthermore, the research of Chelagat et al. (2015) proves that $\mathrm{OCB}$ has a significant positive effect on employee performance. This positive behavior makes employees contribute more to the company, so that the work results achieved are also maximized. In line with research by Ramadhan et al. (2018); Hidayat (2020); Nadeak et al. (2021) also stated that there was a positive and significant relationship on the effect of OCB on employee performance. Furthermore, research from Hidayah (2019) and Arifin (2019) shows that OCB is a variable capable of mediating the influence of spiritual intelligence on employee performance. Radiany \& Radiany (2021) in their research also stated that there was an indirect and significant influence between spiritual intelligence on the performance of education staff at the State University of Malang through OCB.

Organizational Citizenship Behavior (OCB) is able to play a role in shaping one's performance. Kumar (2009) defines OCB as individual behavior that contributes to the creation of organizational effectiveness and is not directly related to the organization's reward system. Organizational Citizenship Behavior (OCB) is characterized by efforts in any form carried out at the discretion of employees that provide benefits to the organization without expecting any reward (Shweta and Srirang, 2010). Sadhegi (2016) also argues that OCB is a behavior to perform tasks that are not part of the formal responsibilities of the company, but are still carried out to improve joint performance. Voluntary participation in OCB has been considered a sign of dedication to the organization.

This research was conducted at the Denpasar Social Service, which is located at Jalan Mulawarman No. 2 Dauh Puri Kaja and is an element of implementing government affairs in the social sector which is the regional authority of Denpasar city. The Denpasar City Social Service has the task of assisting the Mayor of Denpasar in formulating, providing public services and alleviating people with social welfare problems in the city of Denpasar. Based on the results of observations made, in their work activities there are still many obstacles faced so that it is still difficult to achieve organizational goals.

Employee performance that has not been optimal is reflected in the large number of service complaints data at the Denpasar City Social Service and there are still many people with social welfare problems in Denpasar City. These types of complaints are mainly related to the speed of service to the community, sincerity in helping the community, timeliness of service, the ability of staff, and others.

The most complaints are on the speed of service due to the lack of responsiveness of employees in serving the community, then the ability of staff due to public doubts about the ability of employees to provide accurate information, and the timeliness of service that is not fast enough in dealing with problems. Denpasar City Social Service.

The not yet optimal performance of employees at the Denpasar City Social Service is shown from the PMKS (Social Welfare Problems) data in Denpasar which increased in 2018-2019 and has not been able to be completed. Where there are still high number of people with social welfare problems in the city of Denpasar which is caused by the lack of optimal performance of the Denpasar City Social Service employees, from the results of interviews that have been conducted on several employees it is stated that in handling people with social welfare problems, the Denpasar City Social Service has actually done there are many efforts to prevent an increase by carrying out socialization to socioeconomic vulnerable families, launching empowerment programs to help increase productivity and participating in implementing social service facilities which are supported by many collaborations with related parties, but in practice only employees of the Denpasar City Social Service that resolves the issue without the participation of other related parties. OCB behavior is an important behavior to realize the performance of the unit, which in the end will realize a good organizational performance, in accordance with the expectations of the community and all other components.

As for other problems related to spiritual intelligence where there is still a lack of a sense of responsibility for employees in the work given by the Denpasar City Social Service office. The relationship between spiritual intelligence problems and employee performance, for example, employees are often late in carrying out their duties from the agency. This of course can have an impact on employee performance.

Based on the description of the problem phenomenon above, the researchers are interested in raising this topic in research to find out and examine more deeply about the Role of Organizational Citizenship Behavior (OCB) in Mediating the Effect of Spiritual Intelligence on Employee Performance at the Denpasar Social Service.

\section{Literature Review}

\subsection{Employee Performance}

The Indonesian Dictionary quoted and translated by Nawawi (2006:63) says that performance is (a) something that is achieved, (b) demonstrated achievement, (c) work ability. Another definition of performance according to Nawawi (2006: 63) is that performance is said to be high if a 
work target can be completed at the right time or does not exceed the time limit provided. Mangkunegara (2009:9) states that performance is work performance or work (output) both quality and quantity achieved by human resources per unit period of time in carrying out their work duties in accordance with the responsibilities given.

According to Edison (2016) performance is the result of a process that refers to and is measured over a certain period of time based on predetermined provisions or agreements. Performance has a broad meaning, not only the results of work, but including how the work process takes place (Haryanti, 2017).

Based on the understanding of performance put forward by these experts, it can be concluded that performance is a real behavior or work result of a worker concerning the quality and quantity where the work result can be shown concretely and can be measured in an organization or company.

Employee performance in an organization is influenced by many factors (multifactor), both internal and external to the organization. Employee performance in the organization can also be influenced by internal and external factors of employees. In internal employees, employee performance can be influenced by the employee's work ability, employee motivation, including the willingness to take more work outside of his job. Employee work ability is also influenced by employee intelligence including spiritual intelligence.

\subsection{Organizational Citizenship Behavior (OCB)}

Organizational Citizenship Behavior (OCB) is a term for employees who give more value to the work that is their duty as well as added value to the company. OCB is the behavior of individuals who are independent, not directly or explicitly recognized in the reward system and in promoting the effective functioning of the company. OCB is also referred to as extra role behavior because the behavior given by employees exceeds their main task (Putri and Utami, 2017). Organizational Citizenship Behavior (OCB) according to Robbins (2015: 19) is a behavior carried out by an employee that exceeds formal work obligations, but has a good impact because it supports organizational effectiveness.

Maryati and Fernado (2018) state that Organizational Citizenship Behavior (OCB) is employee behavior that is carried out voluntarily, sincerely, and happily without having to be ordered. These behaviors are those that are freely chosen by individuals where they are not directly or explicitly recognized by the formal reward system and aggregately enhance the functioning of the organization. According to Ritonga (2018), the definition of OCB is as follows: 1) Voluntary behavior, not a forced action on matters that prioritize the interests of the organization; 2) Individual behavior as a form of satisfaction based on performance, not formally ordered; 3) Not directly and blatantly related to the formal reward system.
Work behavior like this can affect the performance of an employee. A number of research results have proven the effect of OCB on employee performance such as the results of research conducted by Markose \& Jayachandran, (2009); Chow (2009); Chelagat et al. (2015); Basu et al. (2016); Aponno et al. (2017); and Jiang et al. (2017); Nadeak et al. (2021). Based on this argument, the research hypothesis is built as follows:

Hypothesis 1: OCB has a significant positive effect on employee performance

\subsection{Spiritual Intelligence}

According to Zohar and Marshal (2007), spiritual intelligence is intelligence to deal with and solve problems of meaning and value, namely intelligence to place our behavior and life in the context of a broader and richer meaning, intelligence to judge that one's actions or way of life are more meaningful than others. with others. Khavari (2000) states that spiritual intelligence is intelligence in the human soul. Spiritual intelligence provides the ability to see the positive value in every problem and the wisdom to deal with problems.

Spiritual intelligence equips us to see and solve problems of meaning and value, and then we begin to direct the thoughts and actions in our lives towards broader and meaningful horizons. With spiritual intelligence, we can distinguish more clearly right and wrong (Zohar and Marshall: 2007)

Spiritual intelligence allows humans to be creative, change rules and situations. Spiritual intelligence gives us the ability to discern. Spiritual intelligence gives us a sense of morality, the ability to conform to rigid rules coupled with understanding and love and the equal ability to see when love and understanding reach their limits. We use spiritual intelligence to grapple with good and evil, as well as to imagine unrealized possibilities such as to dream, aspire, and lift ourselves from the low (Zohar and Marshall, 2007).

Based on the understanding of spiritual intelligence put forward by these experts, it can be concluded that spiritual intelligence is the ability to adjust the rules accompanied by an understanding of love and to judge that one's actions or way of life are more valuable and meaningful.

Employees who have a high level of spiritual intelligence have higher work abilities. This is shown from a number of research results conducted by a number of studies. Kulshrestha and Singhal (2017) found that spiritual intelligence had a significant positive effect on employee performance. Other research results that are in line include Lie et al. (2021); Arifin (2019); and Abdolrahimi et al. (2020); Ling et al. (2020). Based on this argument, the research hypothesis was built as follows:

Hypothesis 2: Spiritual intelligence has a significant positive effect on employee performance 
A person's spiritual intelligence can also grow one's work behavior to be willing to do work that is not his responsibility and not receive a reward for the work. An employee's spiritual intelligence affects voluntary work behavior (OCB). This is evidenced by a number of research results, namely Alamanda et al. (2021); Sanjay (2021); Radiany \& Radiany (2021); Herdian et al. (2020). Based on this argument, the research hypothesis was built as follows:

Hypothesis 3: spiritual intelligence has a significant positive effect on OCB

Based on the description as described in the formation of hypothesis 2 and hypothesis 3, where spiritual intelligence affects OCB, and on the other hand OCB affects employee performance, then based on the concept of Baron and Kenny (1986) OCB has the potential to mediate the relationship of spiritual intelligence to employee performance. A number of research results have proven that $\mathrm{OCB}$ can mediate the relationship between spiritual intelligence and employee performance, namely Hidayah (2019); Arifin (2019); Radiany \& Radiany (2021). Based on this argument, the research hypothesis was built as follows:

Hypothesis 4: OCB significantly mediates the relationship of spiritual intelligence to employee performance

\subsection{Conceptual Framework}

The conceptual framework for research on the influence of spiritual intelligence on organizational citizenship behavior (OCB) and employee performance is described in

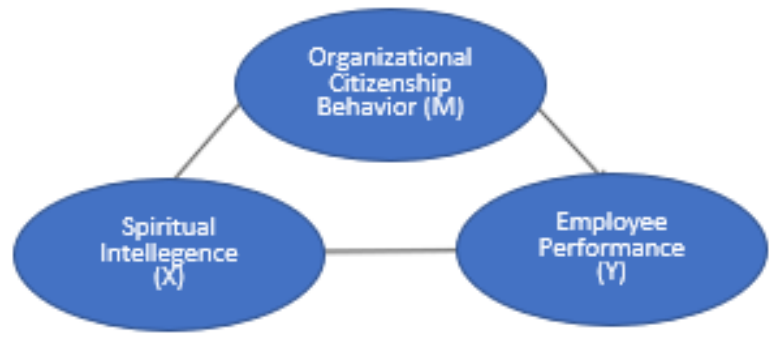

Figure 1. Research Conceptual Framework

\section{Research Metode}

\subsection{Research Design}

This study was designed as an explanatory research to determine the influence between variables in this study, namely the influence of intellectual intelligence on organizational citizenship behavior (OCB) and employee performance, the effect of organizational citizenship behavior (OCB) on employee performance, and the role of organizational citizenship behavior (OCB) in mediating the influence of intellectual intelligence on employee performance at the Denpasar City Social Service Office.

\subsection{Population and Sample}

The population in this study were all employees at the Denpasar City Social Service, totaling 106 employees. The entire population is used as the research sample (census).

\subsection{Variabel and Measurement}

This study uses one exogenous variable, one mediating variable and one endogenous variable. The exogenous variable used is spiritual intelligence, the mediating variable used is OCB, and the endogenous variable used is employee performance. Spiritual intelligence is measured based on 5 indicators, namely: absolute honesty, openness, selfknowledge, focus and contribution and spiritual nondogmatic. The OCB variable was measured based on 5 indicators consisting of altruism, sportsmanship, courtesy, Conscientiousness, and Civic Virtue. While the performance variables are measured through indicators of quality, quantity, timeliness, effectiveness, independence, and commitment.

\subsection{Data Analysis}

\subsubsection{Validity and Reliability Test}

Validity testing is done through convergent validity and discriminant validity. The data is said to be convergently valid if the loading coefficient $>0.50$ and significant. The validity test based on discriminant validity can be seen through the AVE value> 0.50. The reliability test is seen from the Cronbach alpha and composite reliability values. It is said to be reliable if the Cronbach alpha value is $>0.70$. The results of testing the validity of this study in a convergent manner show the outer loading value of 0.582 0.863 (>0.50) and is significant, so that convergently it can be said to be valid. It is also discriminant valid because the value of $A V E$ is greater than the correlation coefficient between other variables, as shown in Table 1 below. Based on the results of data validation, it can be stated that all research data is valid.

Table 1. Discriminant Validity

\begin{tabular}{|c|c|c|c|c|c|}
\hline Variable & AVE & VAVE & $\mathbf{X}$ & $\mathbf{M}$ & $\mathbf{Y}$ \\
\hline $\mathbf{X}$ & 0,563 & 0,750 & 0,000 & & \\
\hline $\mathbf{M}$ & 0,523 & 0,723 & 0,371 & 0,000 & \\
\hline $\mathbf{Y}$ & 0,506 & 0,679 & 0,394 & 0,438 & 0,000 \\
\hline
\end{tabular}

Source: Data processed, 2021

The reliability test is based on the Cronbach Alpha coefficient and composite reliability shows that all variables have a value greater than 0.70 so they are declared reliable, as shown in Table 2. 
Table 2. Cronbach Alpha Coefficient and Composite Reliability

\begin{tabular}{|c|c|c|}
\hline Variabel & Cronbach Alpha & $\begin{array}{c}\text { Composite } \\
\text { Reliability }\end{array}$ \\
\hline X & 0,831 & 0,865 \\
\hline M & 0,748 & 0,845 \\
\hline Y & 0,768 & 0,834 \\
\hline
\end{tabular}

Source: Data processed, 2021

The results of the validity and reliability test concluded that all research data was valid and reliable, so that it could be continued to the next process.

\subsubsection{Fit Model}

The accuracy of the model can be seen through the coefficients of R-Square, Q-Square, and Goodness of fit. Q Square is calculated by the formula: $Q^{2}=1-\left\{\left(1-\mathrm{R}^{2}{ }_{1}\right)(1-\right.$ $\left.\mathrm{R}^{2}{ }_{2}\right)$ \}. GoF value is calculated based on the formula: $\mathrm{GoF}=$ $\left(\mathrm{AVE} X \mathrm{R}^{2}\right.$ ).

The coefficient $\mathrm{R}^{2}$ for the influence of spiritual intelligence $(\mathrm{X})$ on OCB $(\mathrm{M})$ is 0.139 , which means that OCB is $13.9 \%$ influenced by the level of spiritual intelligence of employees, the rest are other factors. The $\mathrm{R}^{2}$ coefficient of spiritual intelligence and OCB variables on employee performance is 0.253 , meaning that $25.3 \%$ employee performance is influenced by spiritual intelligence and OCB, the rest are other factors outside the study. Of the two variables, OCB has a more dominant role than spiritual intelligence, this is indicated by the path coefficient on the relationship between spiritual intelligence and employee performance of 0.268 , while the path coefficient of the relationship between OCB and employee performance is 0.338. Judging from each indicator on the OCB variable, civic virtue (responsibility) has the largest role compared to other indicators, while the second largest position is sportsmanship (tolerance).

The results of the calculation of $\mathrm{Q}-$ Square $\left(\mathrm{Q}^{2}\right)$ are carried out with the following formula:

$$
\begin{aligned}
& \mathrm{Q}^{2}=1-\left\{\left(1-\mathrm{R}_{1}{ }_{1}\right)\left(1-\mathrm{R}^{2}{ }_{2}\right)\right\} \\
& \mathrm{Q}^{2}=1-\{(1-0,139)(1-0,253)\} \\
& \mathrm{Q}^{2}=1-\{(0,861)(0,747)\} \\
& \mathrm{Q}^{2}=1-0,643 \\
& \mathrm{Q}^{2}=0,357
\end{aligned}
$$

The results of the Q2 calculation show a value of 0.357 , meaning that the model can have moderate predictive ability, where the prediction accuracy is only $35.7 \%$.

Calculation of Goodness of Fit (GoF) is done with the following formula: $\mathrm{GoF}=\sqrt{\left(\overline{\mathrm{AVE}} \times \mathrm{X} \mathrm{R}^{2}\right)}$

$$
\begin{aligned}
& \mathrm{GoF}=\sqrt{ }\{(0,563+0,506+0,523) / 3\} \times\{(0,253+0,138) / 2\} \\
& \mathrm{GoF}=\sqrt{ }(0,530667 \times 0,1955) \\
& \mathrm{GoF}=\sqrt{ }(0,103745) \\
& \mathrm{GoF}=0,322095=0,322
\end{aligned}
$$

The results of the GoF calculation show a value of 0.322 (medium). This figure provides an illustration that the model has a moderate level of accuracy.

\subsubsection{Hypothesis Test}

Hypothesis testing is based on the path value and $\mathrm{P}$ Value. The path value is said to be significant if the $\mathrm{P}$ Value $<0.05$. The results of testing the research hypothesis are shown in Figure 1, and reinforced by Table 3 which explains that OCB is a mediation on the influence of spiritual intelligence on employee performance at the Denpasar City Social Service.



Figure 2. SmartPLS Analysis Results 
Table 3. Path Coefficients of Direct and Indirect Effects of Spiritual Intelligence, OCB, and Employee Performance

\begin{tabular}{|c|c|c|c|c|c|}
\hline \multicolumn{2}{|c|}{ Effect Between Variables } & Path Coef & P-value & Information \\
\hline \multicolumn{1}{|c|}{ Independent } & Mediation & Dependent & & & \\
\hline Spiritual Intelligence & OCB & - & 0,371 & 0,000 & significant \\
\hline Spiritual Intelligence & - & Employee Performance & 0,268 & 0,026 & significant \\
\hline- & OCB & Employee Performance & 0,338 & 0,001 & significant \\
\hline Spiritual Intelligence & OCB & Employee Performance & 0,126 & 0,007 & significant \\
\hline
\end{tabular}

Source: Data processed, 2021

Based on Figure 2 and Table 3, it can be explained that spiritual intelligence has a significant positive effect on employee performance, this is indicated by the path coefficient of 0.268 with a p-value of $0.026<0.05$ (significant). These results illustrate hypothesis 2 which states that spiritual intelligence has a significant positive effect on employee performance at the Denpasar Social Service Office is acceptable.

Spiritual intelligence also has a significant positive effect on OCB, this is indicated by the path coefficient of 0.371 with a p-value of $0.000<0.05$ (significant). These results indicate that hypothesis 3 which suggests that spiritual intelligence has a significant positive effect on Organizational Citizenship Behavior (OCB) of employees at the Denpasar Social Service is accepted.

OCB has a significant positive effect on employee performance, this is indicated by the path coefficient of 0.338 with a p-value of $0.026<0.05$ (significant). These results indicate that hypothesis 1 which states that Organizational Citizenship Behavior (OCB) has a significant positive effect on employee performance at the Denpasar City Social Service is accepted.

The next finding is that OCB has a significant positive role as a mediation on the relationship between spiritual intelligence and employee performance, this can be seen from the path value of 0.126 with a p-value of $0.007<0.05$ (significant). The results of this analysis indicate that hypothesis 4 which reads Organizational Citizenship Behavior (OCB) has a significant positive effect on employee performance at the Denpasar City Social Service.

\section{Result and Discussion}

Spiritual intelligence which is reflected by the indicators: absolute honesty, openness, self-knowledge, focus and contribution as well as non-dogmatic spirituality have a significant influence on organizational citizenship behavior (OCB). This means that the increasing level of spiritual intelligence can increase organizational citizenship behavior (OCB) to be higher. The results of this study strengthen the results of previous studies, such as those of Alamanda et al.(2021); Sanjay (2021); and Radiany \& Radiany (2021).
Spiritual intelligence also affects employee performance, meaning that the higher the level of spiritual intelligence, the higher the performance of the employee concerned. The results of this study are in line with the results of research conducted by Kulshrestha and Singhal (2017); Abdolrahimi et al. (2020); and Ling et al. (2020).

Organizational citizenship behavior (OCB) which is one of the three variables in this study which is reflected by indicators of altruism, sportsmanship, courtesy, conscientiousness, and civic virtue shows a significant positive effect on employee performance which is reflected by indicators of quality, quantity, timeliness, effectiveness, independence, and commitment. This means that increasing OCB behavior can improve employee performance. The results of this study are in line with the results of previous studies such as those conducted by Markose \& Jayachandran, (2009); Chow (2009); Chelagat et al. (2015); Basu et al. (2016); Aponno et al. (2017); and Jiang et al. (2017); Nadeak et al. (2021).

Organizational citizenship behavior (OCB) also shows its role as a mediation on the relationship between spiritual intelligence and employee performance. OCB is able to significantly increase the role of spiritual intelligence on employee performance. The results of this study are in line with the results of previous studies such as those conducted by Hidayah (2019); Arifin (2019); Radiany \& Radiany (2021).

\section{Conclusion and Implication}

The results of the study concluded that Organizational citizenship behavior (OCB) has an important role in increasing the influence of spiritual intelligence on employee performance, especially for employees at the Denpasar City Social Service. Employee performance will experience a higher increase by implementing joint improvements to the quality of employee spiritual intelligence and Organizational citizenship behavior (OCB). Increasing organizational citizenship behavior (OCB) is able to enlarge the role of spiritual intelligence on employee performance at the Denpasar City Social Service Office. 


\section{Limitation and Future Research}

The results of this study cannot generally conclude that Organizational citizenship behavior (OCB) is able to enlarge the role of spiritual intelligence on employee performance, because this study was only conducted on employees of the Denpasar City Social Service Office. For this reason, it is necessary to conduct research with the same model in government institutions and private institutions, as well as in profit- and non-profit-oriented institutions.

The research variables used in this research model only consist of spiritual intelligence and Organizational citizenship behavior (OCB) as independent variables, and employee performance as the dependent variable. This model still needs to be developed by including other relevant variables, so that the model becomes more comprehensive.

\section{Reference}

Abdolrahimi, Mohammad, Afshar, Ali, Bevranvand, Gholamreza. 2020. Spiritual Intelligence and its Impact on Police Performance (A Case Study of Boroujerd Police Command). Scientific Journal of Military Psychology. Volume 11, Issue 41. Pages 63-78.

Alamanda, Dini T, Ahmad, Israr, Putra, Halim D, Hashim, Nik A. 2021. The role of spiritual intelligence in citizenship behaviours amongst Muslim staff in Malaysia. HTS Teologiese Studies/Theological Studies ISSN: (Online) 2072-8050, (Print) 0259-9422.

Aponno, E.,H., Brasit, N., \& Taba, I. M. 2017. Factors That Influence Organizational Citizenship Behavior And Employees Performance With Local Culture Moderation Pela Gandong. Scientific Research Journal SCIRJ, Vol. 5, No. 6, pp. 10-26.

Arifin, Fatikha Floressya. 2019. Efek Mediasi Organizational Citizenship Behavior di antara Kecerdasan Emosional dan Kecerdasan Spiritual terhadap Kinerja Tenaga Kependidikan Universitas Negeri Malang. Jurnal Ilmiah Administrasi Publik. JIAP Vol 5, No 2, pp 146-153.

Basu, E. P., Rabindra, K., \& Tewari, H. R. 2016. Impact of Organizational Citizenship Behavior on Job Performance in Indian Healthcare Industries: The Mediating Role of Social Capital. International Journal of Productivity and Performance Management, Vol. 66, No. 6, pp. 780-796.

Chelagat, L. J., Chepkwony, P. K., \& Kemboi, A. 2015. Effect of organizational citizenship behavior on employee performance in the banking sector, Nairobi County, Kenya. International Journal of Business, Humanities and Technology, 5(4), 55-61.

Chow, I. H. S. 2009. The Relationship Between Social Capital, Organizational Citizenship Behavior, and Performance
Outcomes: An Empirical Study From China. SAM Advanced Management Journal, Vol.74, No.3, pp. 44-53.

Edison, Emron. 2016 Manajemen Sumber Daya Manusia. Alfabeta. Bandung.

Efendi. Agus. 2005. Revolusi Kecerdasan Abad 21. Bandung: Alfabeta.

Haryanti, Titik (2017), Pengaruh Motivasi Berprestasi terhadap Kinerja Gurudi SMK Tunas Pemuda, Research and Development Journal of Education, 4 (1), 44-52.

Herdian, Panji Dwi, Nugroho, Riyadi, Sumiati. 2020. The Effect Of Work Motivation And Spiritual Intelligence On Employee Performance With Organizational Citizenship Behaviour (OCB) As Intervening Variables. JMM17 Jurnal Ilmu Ekonomi dan Manajemen, Vol. 07 No. 01, hal. 1-12. ISSN; 2355-7435.

Hidayah, R. 2019. Pengaruh Kecerdasan Spiritual Terhadap Kinerja Karyawan Melalui Organizational Citizenship Behavior Pada Pt Pln (Persero) Area Bojonegoro. Jurnal Ilmu Manajemen Volume 7 Nomor 1 - Jurusan Manajemen Fakultas Ekonomi Universitas Negeri Surabaya, 58-65.

Hidayat, Deddy Rahman. 2020. Job Satisfaction, Organizational Commitment, Organizational Citizenship Behavior (OCB), and Performance of theVocational High School Teachers. Journal Of K6,Education,And Management, Vol. 3, No. 1, 32-39.

Idrus, 2002, Kecerdasan Spiritual Mahasiswa Yogyakarta, Psikologi Phronesis, Jurnal Ilmiah dan Terapan, Vo.4, No.8.

Indriani, Heny, dan Inayah Adi Sari. 2017. Pengaruh Kecerdasan Spiritual, Kecerdasan Emosi, Sikap Budaya Organisasi, dan Komitmen Organisasi Terhadap Organizational Citizenship Behavior pada Guru Sekolah Menengah Kejuruan Negeri Kelompok Teknologi dan Industri Kabupaten Tegal. Jurnal Bisnis Manajemen (JBIMA), No. 2, Vol. 5.

Jiang, W., Zhao, X., \& Ni, J. 2017. The Impact of Transformational Leadership on Employee Sustainable Performance: The Mediating Role of Organizational Citizenship Behavior. Sustainability MDPI Journal, Vol.9, pp.117.

Khairat, Hayatul. 2017. "Kecerdasan Emosional, Kecerdasan Intelektual, Kecerdasan Spiritual Dan Komitmen Organisasi Terhadap Kinerja Auditor". JOM Fekon Vol 4 No.1.

Khavari, Khalil A (2000). Kecerdasan Spiritual( A pratictical guide to personal happiness). Kanada: Gunung Putih Publications.

Kulshrestha, S., \& Singhal, T.K. (2017). Impact Of Spiritual Intelligence On Performance and Job Satisfaction: A Study On School Teachers. International Journal of Human Resource \& Industrial Research, 4(2): 1-6. 
Kumar, K. (2009). Linking the 'Big Five' personality domains to organizational citizenship behavior. International Journal of Psychological Studies, 1(4).

Lie, Darwin, Simatupang, Sudung, Harini, Sri, Dharma, Edy. Sudirman, Acai. 2021. Teacher Performance in Terms of The Aspects of Intellectual Intelligence, Emotional Intelligence and Spiritual Intelligence. JPI, Vol. 10 No. 2.p-ISSN: 2303-288X, e-ISSN: 2541-7207.

Ling, Foo Choi, Kartar Singh, Jugindar Singh, Arumugam, Thilageswary. 2020. Employee Contextual Performance, Social. Intelligence, Spiritual Intelligence: A Quantitative Study In Malaysia. International Journal of Psychosocial Rehabilitation, Vol. 24, Issue 02, 2020 ISSN: 1475-7192.

Markose, B., \& Jayachandran, S. 2009. The Impact of Organizational Citizenship Behaviors on Goal Orientation and Performance of Salespeople. International Journal of Business Insights \& Transformation, Vol.2, No.1, pp. 16-27.

Maryati, Tri, Fernado, Aulia. 2018. Peran Organizational Citizenship Behaviour (OCB) dalam Memediasi Pengaruh Motivasi Intrinsik Dan Kepuasan Kerja Terhadap Kinerja Karyawan Pada PT.Cinemaxx Branch Lippo Plaza Yogyakarta. Jurnal Bisnis Teori dan Implementasi, Vol. 9, No. 2 : 158-173.

Moeheriono. 2012. Pengukuran Kinerja Berbasis Kompetensi. Jakarta: Raja Grafindo Persada.

Moosapour, Sodeif. 2013. Spiritual Intelligence Relationship with Organizational Citizenship Behavior of High School Teachers in Germi City. Journal of Business Management and Social Science Research (JBM, SSR), Vol. 2, No.10.

Nadeak, Multi, Widodo, Adi, Asbari, Masduki, Novitasari, Dewiyana, Purwanto, Agus. 2021. Understanding the Links between Coaching, OCB, and Individual Performance among MSME Employees. International Journal Of Social And Management Studies (IJOSMAS). Volume: 02 No. 04. Pp.6580 .

Nawawi, Hadari. (2006). Evaluasi dan manajemen kinerja di lingkungan perusahaan dan industri. Yogyakarta: Gadjah Mada Univercity Press.Perawat. Iqtishoduna, 14(1), 71-86. https://doi.org/10.18860/iq.v0i0.4830

Putri, Yumna, Dahlian., Hamidah, Nayati, Utami. 2017. Pengaruh Organizational Citizenship Behavior (OCB) Terhadap Kinerja Karyawan ( Studi Pada Tenaga Ruang Rawat Inap Rumah Sakit Baptis Batu), JAB, Jurnal Administrasi Bisnis, Vol. 46, No. 1, Mei 2017, Malang : Fakultas Ilmu Administrasi Universitas Brawijaya.
Radiany, M. Andri, Radiany, Ade Asria. 2021. Mediation Effects Organizational Citizenship Behavior Between Emotional and Spiritual Intelligence on Lecturer Performance at The College Economics. Ilomata International Journal of Management (IJJM). P-ISSN: 2714-8971; E-ISSN: 2714-8963, volume. 2, Page No: 72-81.

Ramadhan, Fairico Putra, Heru Susilo, Edlyn Khurotul Aini. 2018. Pengaruh Organizational citizenship behavior (OCB) dan Good Corporate Governance (GCG) terhadap kinerja karyawan (Studi pada karyawan PT Taspen (Persero) Kantor Cabang Malang). Jurnal Administrasi Bisnis (JAB) Vol 55 No.2.

Ratnasari, Sri Langgeng, Supardi, Supardi, Nasrul, Herni Widiyah. 2020. Kecerdasan Intelektual, Kecerdasan Emosional, Kecerdasan Spiritual, dan Kecerdasan Linguistik Terhadap Kinerja Karyawan. Journal of Applied Business Administration. Vol 4 No 2.

Ritonga, E. (2018). Peran Organizational Citizenship Behavior Sebagai Pemediasi Pengaruh Kepuasan Kerja Terhadap Kinerja.

Robbin \& Judge. 2015. Perilaku Organisasi Edisi 16. Jakarta. Salemba Empat.

Sadhegi. 2016. The relationship between organizational citizenship behavior and organizational performance (case study: Agricultural Jihad Organization of Mazandaran Province). Problems and Perspectives in Management. Vol. 14 No. 3: 317-324.

Sanjay, I Joe. 2021. The Impact of Spiritual and Emotional Intelligences in Employee Engagement and Organizational Citizenship Behavior. International Journal of Aquatic Science, ISSN: 2008-8019. Vol 12.

Sedarmayanti. 2011. Manajemen Sumber Daya Manusia. Reformasi Birokrasi dan Manajemen Pegawai Negeri Sipil, Cetakan Kelima, PT Refika Aditama,Bandung.

Shweta, J., and Srirang, J. 2010. Determinants of Organizational Citizenship Behavior: A Review of Literature, Journal of Management and Public Policy, Vol 1 No 2, pp.27-36.

Zohar, Danah \& Marshall, Ian. 2002. SQ: Memanfaatkan Kecerdasan Spiritual dalam Berpikir Integralistik dan Holistik Untuk Memaknai Kehidupan. Bandung: Mizan.

Zohar, Danah \& Marshall, Ian. 2007. Kecerdasan Spiritual (SQ) Memanfaatkan Kecerdasan Spiritual Dalam Berpikir Integralistik dan Holistik Untuk Memaknai Kehidupan. Bandung: Mizan. 